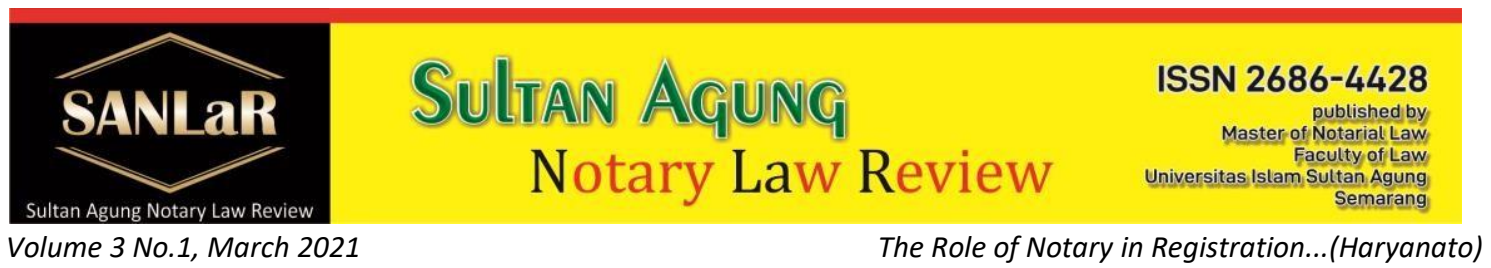

\title{
Role of Notary in Registration of Fidusian Warranties to Obtain Fidusian Warranty Certificate
}

\author{
Haryanato*)
}

$\left.{ }^{*}\right)$ Student Master of Notary Law, Faculty of Law, Universitas Islam Sultan Agung Semarang, Indonesia, E-mail: manusiaputih.tanparupa@gmail.com

\begin{abstract}
In this modern era and the development of technology that continues to develop significantly encourages many parties to make better use of technology wisely \& well, and maximally, this is also utilized by the government. In providing public services including the Directorate General of General Legal Administration (Ditjen AHU) Ministry of Law and Human Rights of the Republic of Indonesia. Launched the Online Fiduciary Guarantee Certificate registration program. Which is where the role of the Notary in this case plays a very important role before the issuance of the online program Creditor or Fiduciary Security Recipient or Proxy to obtain a Fiduciary Guarantee Certificate must register conventionally or manually where the applicant must come to the office of the Directorate General of General Legal Administration (Ditjen AHU) of the Ministry Law and Human Rights of the Republic of Indonesia in their respective provinces, which of course require a lot of time and money. So with the implementation of the Fiduciary Guarantee Certificate registration program online. Of course, you get a lot of benefits both in terms of economics and efficiency, of course, more practical and faster. So with the implementation of the Fiduciary Guarantee Certificate registration program online. Of course, you get a lot of benefits both in terms of economics and efficiency, of course, more practical and faster. So with the implementation of the Fiduciary Guarantee Certificate registration program online. Of course, you get a lot of benefits both in terms of economics and efficiency, of course, more practical and faster. formulation of the problem of how the Notary's Role in Fiduciary Security Certificate Registration to Obtain a Fiduciary Guarantee Certificate, as well as Obstacles and Solutions in Implementing Online Fiduciary Guarantee Certificate Registration at the Directorate General of General Law Administration (Ditjen AHU), Ministry of Law and Human Rights of the Republic of Indonesia With the enactment of Online Fiduciary Registration at the Directorate General of General Legal Administration (Ditjen AHU), Ministry of Law and Human Rights of the Republic of Indonesia is very beneficial for the general public, especially Debtors, Creditors, Notaries and the Government itself as well as financing institutions. Although there are still good obstacles in the nature of the regulatory substance of Act No. 42 of 1999 concerning Fiduciary Security, there is a lack of discipline in law and culture in society. Because if the rule of law, lack of legal discipline, and community culture are not improved, then justice, legal certainty, and benefits will not be felt by the community itself. It is hoped that in the future it will be better and require commitment from the general public, especially those related to the Fiduciary Guarantee.
\end{abstract}

Keywords: Notary; Fiduciary Certificate; Online Fiduciary. 


\section{Introduction}

In an era that is all digital with various advances in all fields as well as the increasing needs of the community, especially problems of transportation, economy and technology as well as a growing population and growing rapidly, the demand for the availability of various facilities that support people's lives has also increased. This encourages the government and the private sector to implement changes to the increasingly modern public services using technological means, especially in the field of law. The rapid population development and unstable economic development have an impact on the difficulty of individuals to be able to meet their needs, sometimes people in meeting their needs, they build (guarantee) their vehicles, both motorbikes and cars, to second parties (Banks/creditors) and people who want/own good vehicles motorbikes or cars with a modest income are usually made in installments (credit) to the Financing Institution. To provide legal certainty as well as legal protection for both the Debtor as the party who enjoys the facilities of the Financing Institution and the Creditors as the Party that provides Financing facilities to the Debtor. The parties will usually enter into an engagement and agreement and will provide a Guarantee. The term guarantee comes from the Dutch language, ${ }^{1}$ which means responsibility, so that the guarantee can be interpreted as a liability, In this case what is meant is the responsibility for all the engagements of a person as mentioned in Article 1131 of the Criminal Code as well as dependents for a certain engagement from a person, such as those in Civil Code Articles 1139-1149 concerning Preferred Receivables, Articles 1150-1160 concerning Pawning, Articles 1162-1178 concerning Mortgages, Articles 1820-1850 concerning Liability of Debt, and finally as stipulated by jurisprudence is Fiduciary. Types of Guarantee According to its nature, the guarantee is divided into 2 (two), namely: ${ }^{2}$ General guarantees, namely guarantees provided for the interests of all creditors and relating to all assets of the debtor, this is in accordance with Article 1131 of the Criminal Code, special guarantees, namely guarantees in the form of appointment or delivery of certain items specifically, as collateral for the repayment of debtor's obligations/debts to certain Creditors, which only applies to that particular Creditor, both materially and individually. This special guarantee can be divided into 2 (two), namely: ${ }^{3}$ Collateral is material in nature, namely the existence of certain objects that are used as collateral. In this case there is no limit to the items that can be used as collateral, it's just that the guaranteed material must belong to the party that guarantees the property. This guarantee can be institutionalized in the form of a mortgage, mortgage, fiduciary and pawn, while the characteristics of the material security are: Directly related to certain objects, can be defended against anyone, always follows the object, can be transferred, gives precedence to creditors who hold rights This material guarantee is for the sale of the property which is guaranteed by property rights, if the Debtor is in default of his obligations to the Creditors. Regarding

\footnotetext{
${ }^{1}$ Salim HS. (2004). Perkembangan Hukum Jaminan Di Indonesia, Jakarta : PT Raja Grafindo Persada. p.22.

2 Dwi Fratmawati. (2004). Perlindungan Hukum Bagi Kreditor terhadap Pelaksanaan Fidusia, Semarang, Unissula. p. 17.

3 Ibid., p. 18.
} 
the material guarantee, it is divided into 4 (four), namely: Pawn, Mortgage, Collateral that is individual in nature, namely that there is a certain person who is able to pay or meet the achievement if the debtor is in default, in this case, that the claim to fulfill the guaranteed debt repayment can only be made privately by the creditor as the owner of the receivables with the guarantor, and cannot be used to harm the party. other. For whatever reason. In this guarantee, the principle of equality applies, namely that there is no difference between receivables that come first and those that come later. So all creditors on the assets of the Debtor have the same position, regardless of the sequence of events. In this case the limitation for the discussion is the collateral for movable objects, namely the Fiduciary guarantee. From the phenomenon above, the increasing number of Fiduciary Guarantee rights holders (Creditors), according to the applicable law, the role of a Notary is very necessary to register and obtain a Fiduciary Guarantee certificate quickly and at low cost. Due to the limited number of employees at the Ministry of Law and Human Rights of the Republic of Indonesia, it is certain that they will be neglected by the large number of Notaries who apply for fiduciary guarantee certificates. Technology has made more advances in thinking and acting. These advances are ultimately to achieve their life goals faster, through unlimited access to information, technology offers facilities in various human activities and in the end the AHU Online program was launched, which was initiated by the Directorate General of AHU, Ministry of Law and Human Rights of the Republic of Indonesia. The Electronic Fiduciary Registration Administration System was formed on March 5, 2013 by the Directorate General of General Legal Administration (Ditjen AHU) based on the Circular Letter of the Directorate General of AHU No. AHU-06.0T.03.01 Year 2013 concerning the Enforcement of an Electronic Fiduciary Security Registration Administration System (Online System) as a substitute for the manual fiduciary security registration system. Then the system underwent another development to become the Electronic Fiduciary Registration Administration System in 2014. Among the three fiduciary security registration systems there are a number of similarities, namely those related to the concepts and principles of fiduciary security registration, the position of the fiduciary recipient as creditor preference, and the power of executor in the certificate. Fiduciary Guarantee. Then there are also differences that are related to registration procedures, registration documents, fiduciary registration statements, and Fiduciary Guarantee Certificates. in order to improve services to people who need legal services in the field of fiduciary security. ${ }^{4}$ The establishment of this system is a manifestation of the Ministry of Law and Human Rights' efforts to enforce the contents of Article 14 Paragraph (1) of the Fiduciary Guarantee Law (UUJF) which reads: "The Fiduciary Registration Office issues and submits to Fiduciary Recipients the Fiduciary Guarantee Certificate on the same date as the date of receipt. application for registration ", 5 This article cannot be implemented perfectly in the old system, namely the manual fiduciary registration system because the number of human resources (SDM) and infrastructure in the

\footnotetext{
${ }^{4}$ http://download.portalgaruda.org/article.phpkepastianhukumdalampemberlakuansistemadministrasip endaftaranjamminanfidusiaelektronikterkaitdenganlaranganfidusiaulang. accessed on 27 October 2020, at 14.35 WIB.

${ }^{5}$ Act No. 42 of 1999 concerning Fiduciary Guarantee Article 14 paragraph (1).
} 
Fiduciary Registration Office (hereinafter referred to as KPF) is not proportional to the large number of applications for guarantee registration. Fiduciary enters every day, resulting in a buildup of Fiduciary Security registration archives at KPF and creates legal uncertainty. Electronic registration of fiduciary guarantees also aims so that all fiduciary registration registrations can be recorded nationally in the DG AHU database so that the principle of publicity increases. Various parties who often deal with matters in the field of fiduciary security, starting from the fiduciary (Debtor), fiduciary recipient (Creditor), ${ }^{6}$ Principle of Publicityis one of the features of modern debt guarantees with the aim of increasing the publication of a debt guarantee, so creditors or the general public can find out or have access to important information around the debt guarantee, so it is hoped that the debtor cannot deceive creditors or prospective creditors by fiduciary once again or even sell the object of the Fiduciary Guarantee without the knowledge of the original creditor. After running for almost three years, various benefits have begun to be felt by applicants for fiduciary registration, including making registration applications easier without having to visit the Fiduciary Registration Office (KPF) and the Fiduciary Guarantee Certificate issued on time and can be printed by the applicant himself. But in addition to these various advantages,

"The registration statement as referred to in paragraph (1) contains:

1. The identity of the party giving and receiving fiduciary.

2. Date, fiduciary guarantee deed number, name, place of domicile of the notary who made the fiduciary guarantee deed.

3. Principal agreement data guaranteed by fiduciary.

4. A description of the objects that are the object of fiduciary security.

5. Guarantee value; and

6. The value of the object which is the object of fiduciary security. "

And Article 14 paragraph (2) reads: "Fiduciary Guarantee Certificate which is a copy of a fiduciary register book containing notes on matters as referred to in Article 13 paragraph (2). The more intelligent the Indonesian people are, the more advanced their knowledge and intellectuality, the public wants all affairs to be fast, precise and accurate and at low cost, including matters with fiduciary guarantees carried out by the public with banks. The binding of a fiduciary security deed is an agreement that arises from an agreement, which is regulated in Article 1338 of the Civil Code, which recognizes the existence of freedom of contract, with the limitation that the agreement cannot conflict with statutory regulations and must be based on good faith. Guarantee Law according to the conclusion in the Guarantee Law Seminar in 1978 is a legal provision that regulates the legal relationship between the Guarantee provider (Debtor) and the Guarantee recipient (Creditor) as a result of the imposition

${ }^{6}$ http. Op.cit. 
of a certain debt (Credit) with a Guarantee (certain object or person). ${ }^{7}$ Meanwhile, according to Ali Mansyur, guarantee law is a law that regulates the legal relationship between creditors and debtors related to the imposition of collateral for credit extension. ${ }^{8}$ Then this fiduciary guarantee is needed. Fiduciary is the transfer of ownership rights to an object on the basis of trust provided that the object whose ownership rights are transferred remains in the control of the owner of the object. ${ }^{9}$ The word Fiduciair which means "trustworthiness" is addressed to the trust given back and forth by one party to another, that what comes out is shown as a transfer of property, in fact (inside, internally) is only a guarantee for a debt. ${ }^{10}$ Meanwhile, the Fiduciary Guarantee is the right of guarantee for movable objects, both tangible and intangible and immovable objects, especially buildings that cannot be encumbered with the Mortgage Rights as referred to in Act No. 4 of 1996 concerning Mortgage Rights which remain under the control of the Fiduciary, as collateral for the settlement of certain debts, which gives the Fiduciary priority over other creditors. ${ }^{11}$ The term guarantee comes from the Dutch language, namely Zekerheid or Cautie, which means responsibility, so that the guarantee can be interpreted as dependency, in this case what is meant is the coverage for all engagements from a person as mentioned in Article 1131 of the Criminal Code as well as coverage for a certain engagement from someone, as stated in Civil Code Articles 1139-1149 concerning Preferred Accounts Receivable, Articles 1150-1160 concerning Pawning, Articles 11621178 concerning Mortgages, Articles 1820-1850 concerning Liability of Debt, and finally as determined by jurisprudence is fiduciary. According to Hartono Hadusoeprapto and M. Bahsan, a guarantee is something that is given to creditors to create confidence that the debtor will fulfill obligations that can be valued in money arising from an engagement. ${ }^{12}$ The term Guarantee Law is a translation of security of law, zekerheidstelling, or zekerheidsrechten. The legal term guarantee includes both personal and personal guarantees. Material guarantees include preferential Payable, Pawning, and Mortgage. Meanwhile, individual guarantees, namely debt coverage (borgtocht). In connection with the definition, according to Sri Soedewi Masjhoen Sofwan, the guarantee law regulates the juridical construction of the provision of credit facilities, by guaranteeing the items purchased as collateral. Such regulations must be sufficiently convincing and provide legal certainty for credit institutions, both domestic and foreign. The existence of such guarantee institutions and institutions must be aligned with the existence of large credit institutions. ${ }^{13}$ The term Guarantee Law is a translation of security of law, zekerheidstelling, or zekerheidsrechten. The legal term guarantee includes both personal and personal guarantees. Material guarantees include preferential Payable, Pawning, and Mortgage. Meanwhile, individual guarantees, namely debt coverage (borgtocht). In connection with the

\footnotetext{
${ }^{7}$ Rachmadi Usman. (2009). Hukum Jaminan Keperdataa, Jakarta: Sinar Grafika, p.1-2.

${ }^{8}$ Ali Mansyur. Hukum Perdata Jaminan. Semarang, Bagian Hukum Perdata Unissula, p.3.

${ }^{9}$ Act No. 42 of 1999 concerning Fiduciary Guarantee Article 1 paragraph (1).

${ }^{10}$ R.Subekti (1978). Jaminan-Jaminan Untuk Pemberian Kredit menurut Hukum Indonesia, Bandung: Alumni. p.76.

${ }^{11}$ Act No. 42 of 1999 concerning Fiduciary Guarantee Article 1 paragraph (2).

12 Salim HS, op Cit., p.22.

${ }^{13}$ Salim HS.op cit., p 5-6.
} 
definition, according to Sri Soedewi Masjhoen Sofwan, the guarantee law regulates the juridical construction of the provision of credit facilities, by guaranteeing the items purchased as collateral. Such regulations must be sufficiently convincing and provide legal certainty for credit institutions, both domestic and foreign. The existence of such guarantee institutions and institutions must be aligned with the existence of large credit institutions. ${ }^{14}$ From the opinion mentioned above that the formulation of the definition of Guarantee Law can be concluded that the essence of the Guarantee Law is a legal provision that regulates the legal relationship between the guarantor or debtor and the guarantor or creditor as the imposition of a certain debt or credit with a guarantee (certain objects or people). Property rights that are debt repayment (guarantee rights) are collateral rights attached to the creditor which authorizes the execution of objects that are used as collateral if the debtor defaults on an achievement (agreement). Meanwhile, guarantees that are born because of the agreement are guarantees that must be agreed upon in advance between the parties. This guarantee agreement is an accessoir agreement, this, the guarantee right cannot exist because the guarantee right is an additional accessoir agreement to the main agreement, namely the payable agreement (credit agreement). In principle, the position of Creditors on their bill against a Debtor is the same high, therefore they are called Concurrent Creditors. This means that in principle they have the same rights to general guarantees, which is given by Article 1131, namely for all assets of the Debtor, the opportunity for Creditors to be paid in full of their bills, in principle is the same, because if the assets of the Debtor are not sufficient to guarantee all owed. Therefore, for the sale of the Debtor's assets, Creditors share the pond's, in the sense that it is equal to the size of their bill (Article 1132 of the Civil Code).${ }^{15}$ If there are creditors who want more position than their fellow concurrent creditors, the creditors can agree on collateral rights, both individual security rights, such as the liability debtor and there is a borg that gives him a better position, because there is more than a person who can be billed, or has agreed to the right to guarantee the material which gives him the right to take precedence in taking full payment of the proceeds from the sale of certain objects or a group of certain objects belonging to the Debtor, the guarantor, and sometimes besides that it is also facilitated in exercising his rights. ${ }^{16}$ There are three levels of creditors, namely: Separatist creditors, namely creditors who have property security rights, including: mortgage holders, pledge holders, fiduciary security holders, mortgage rights holders, etc., preferent creditors, namely creditors with special privileges like those regulated in Article 1139 and Article 1149 of the Civil Code, concurrent creditors or also known as competitive creditors, because they do not have special guarantees and do not have special rights, so that their position is the same as creditors without other guarantees based on the principle of parity cridetorium. Fidusia or the complete Fiduciare Eigendomsoverdracht, according to its origin, comes from the Roman word fides which means belief. Indeed, the Fiduciary Construction is that the legal relationship

\footnotetext{
14 J.Satrio (2002). Hukum Jaminan, Hak Jaminan Kebendaan, Bandung: PT.Citra Aditya Bakti, p.68-69.

15 Ibid, p.69

${ }^{16}$ Oey Hoey Tiong. (2000). Fidusia sebagai Jaminan Unsur-unsur Perikatan, Jakarta : Ghalia Indonesia, p.21.
} 
between the Fiduciary-giving debtor and the Fiduciary's creditor is a relationship based on the principle of trust. The Fiduciary Giver believes that the creditor of the Fiduciary recipient wants to return the property that has been handed over to him, after the Debtor has paid off his debt, the creditor also believes that the fiduciary will not abuse collateral under his control and wants to keep the collateral as a good house father. ${ }^{17}$ Fiduciary is a term that has long been known in Indonesian. Likewise, this term is used in Act No. 42 of 1999 concerning Fiduciary Security. In Dutch terminology, this term is often referred to in full, namely Fiduciare Eigendom Overdracht. The definition of fiduciary is the transfer of ownership rights to an object based on trust, provided that the object whose ownership rights are transferred remains under the control of the owner of the object. Fiduciary is known as a form of recognition of the transfer of ownership rights in a constitutum possessorium, namely the transfer of ownership rights to an object where the object remains in the possession of the object, while only the right of ownership is transferred. In the manual fiduciary security registration system, a physical document in the form of a fiduciary guarantee registration statement is required (blank provided by Fiduciary Registration Office (KPF), a letter of application for fiduciary security registration, a copy of the Fiduciary Security Deed, a power of attorney to register, proof of PNBP payment and a photocopy of proof of ownership of the object to the KPF as a registration requirement, while in the administrative system of fiduciary security registration electronically all the required data only needs to be filed. input online without having to submit physical documents The concept of Fiduciary Security registration is carried out to fulfill the principle of publicity. Although the registration procedure for fiduciary security continues to develop until now, in essence it is hoped that with the concept of registration for the object of the Fiduciary Guarantee carried out by the recipient of this Fiduciary, the principle of publicity is fulfilled and legal protection for the parties in the fiduciary agreement can also be more guaranteed because Fiduciary cannot trick prospective Creditors (third parties) into refiduciarying.

\section{Research Methods}

The research approach used in this research is to use an empirical/sociological juridical review approach. The empirical juridical approach is a method of procedure used to solve problems by examining secondary data first, then continued by using research on primary data in the community or in the field. The empirical juridical method is used because it is an approach that is researched and the research results obtained in relation to its legal aspects. ${ }^{18}$

\footnotetext{
17 Ibid, p.59.

${ }^{18}$ Yunaldi. (2015). Usulan Penelitian, Program Magister Ilmu Hukum. Semarang: Unissula.p.30.
} 


\section{Results and Discussion}

3.1 Development of information technology gives Lex et Societatis changes to the order of human life

The Fiduciary Guarantee has also experienced this change, in which the current Fiduciary Security registration procedure has shifted from being manual or conventional to an electronic or online system. This is increasingly felt after the issuance of the Circular of the Director General of General Legal Administration of the Ministry of Law and Human Rights of the Republic of Indonesia Number AHU06.OT.03.01 dated March 5, 2013 concerning the Application of the Fiduciary Security Registration Administration System electronically (Online system) which is then regulated in the Regulation of the Minister of Law and Human Rights Number 9 of 2013 concerning the Enforcement of an Electronic Fiduciary Registration Administration System.

Regulation of the Minister of Finance of the Republic of Indonesia No. 130/PMK.010/2012 Government Regulation Number 21 of 2015, regarding the Fiduciary Guarantee Registration Procedures and Fees for Making a Fiduciary Security Deed, Government Regulation Number 10 of 2015 Concerning Amendments to Government Regulation Number 45 of 2014 concerning Types and Rates of Non-Tax State Revenues Applicable to the Ministry of Law and Human Rights, Decree of the Minister of Justice and Human Rights of the Republic of Indonesia Number: M.02.PR.07.10 of 2002 concerning amendments to the decision of the minister of Justice and Human Rights of the Republic of Indonesia Number: M.03.PR.07.10 of 2001 concerning the opening of Fiduciary Registration offices in all regional offices Ministry of Law and Human Rights of the Republic of Indonesia, Regulation of the Minister of Law and Human Rights Number: 8 of 2013 concerning Delegation of the Signing of Fiduciary Guarantee Certificate, Minister of Law and Human Rights Regulation Number: 10 of 2013 concerning the procedure for Electronic Fiduciary Registration. To provide safe, comfortable, fast and clean services in the implementation of the Fiduciary Security registration administration system. A notary with a character on the one hand as a "general official" and on the other hand as a "professional" must truly understand, live and practice the Law on Notary Position and the Notary Code of Ethics as well as applicable laws and regulations, in order to avoid actions that can threaten his position.

The designation as a public official as stated in Act No. 30 of 2004 as amended by Act No. 2 of 2014 is because a Notary is the only position authorized in making authentic deeds. The authority and obligations of the notary regarding actions, agreements and stipulations required by a general rule or by interested parties are required to be stated in an authentic deed by guaranteeing the certainty of the date, keeping the deed, and provide grosse, copy, and excerpt thereof, as long as the making of the deed by a general rule is not assigned or excluded to other public officials. The granting of the qualification of a Notary as a public official is related to his authority in Article 15 of the UUJN, namely to make an authentic deed as long as it is not assigned to an authorized official. This fiduciary registration, notary in serving the interests of the public, must act in accordance with its authority and must be carried out in a professional manner. Notary in every act cannot be held accountable. Notary is the 
same as other professions, which in every action must be able to be held accountable legally, more specifically in terms of fiduciary registration.

The Fiduciary Guarantee Act No. 42 of 1999 already requires that fiduciary be made in a Notary Deed and then registered, because fiduciary registration creates preference rights for fiduciary recipients. The fact is that for fiduciary registration, only banking institutions make fiduciary certificates in the form of a Notary. Financing institutions usually do not carry out fiduciary registration because the making of the act is under hand. This will cause risk in the event of default, due to the lack of legal certainty of the act. It is feared that later fiduciary recipients will find it difficult to withdraw their collateral, so it is not uncommon for these financial institutions to be reported as perpetrators of confiscation.

In relation to the provisions above, regarding the process of fiduciary loading or stages of fiduciary loading are as follows:

a. The first process, by making a basic agreement in the form of an agreement credit; namely the agreement between Creditors and Debtors.

b. The second process, the imposition of objects with fiduciary security which is marked by the creation of a Fiduciary Security Deed (AJF), which contains the day, date, time of manufacture, the identity of the parties, data on the principal fiduciary agreement, a description of the fiduciary object, the value of guarantee and the value of the fiduciary security object;

c. The third process is the registration of the Fiduciary Security Deed (AJF) at the fiduciary registration office, which will then issue a Fiduciary Guarantee Certificate to creditors as fiduciary recipients;

A fiduciary guarantee that a Fiduciary Guarantee certificate is not made creates legal consequences are complex and risky. Creditors can exercise their execution rights because they are considered unilateral and can lead to arbitrariness from the Creditors. It could also be because, considering that the financing of the object of Fiduciary is usually not fully in accordance with the value of the goods. Or, the Debtor has fulfilled part of the obligations of the agreement made, so that it can be said that above the item stands partially owned by the Debtor and partly by Creditors. Especially if the execution is not through an official price rating agency or a public auction agency. Such actions can be categorized as Unlawful Acts (PMH) according to Article 1365 of the Civil Code and can be sued for damages.

In the conception of criminal law, execution of a fiduciary object under hand is a criminal offense in Article 368 of the Criminal Code if the creditor carries out coercion and threat of confiscation. This situation can occur if the creditor in the execution enforces and takes goods unilaterally, even though it is known that the goods are partly or wholly owned by someone else. Although it is also known that some of the goods belong to the creditor who wants to execute, but is not registered with the fiduciary office. Even the imposition of other articles can occur considering that everywhere execution is not an easy thing, for that it requires legal guarantees and legal support from legal officials. This is the urgency for balanced legal protection between Creditors and Debtors. In the Fiduciary Security Registration Administration System manually is no longer enforced as stated in the Circular of the Director General 
of General Legal Administration of the Ministry of Law and Human Rights of the Republic of Indonesia Number AHU-06.0T.03.01 in number 2, namely Fiduciary Registration Offices throughout Indonesia In carrying out its duties and functions, no longer accepting applications for registration of fiduciary security manually and also informing applicants to submit applications for registration of Fiduciary Security electronically.

In number 4 it explains that for the application for registration of Fiduciary Security that has been submitted to the Fiduciary Security registration office and has paid the Non-Tax State Revenue (PNPB) fee prior to the enactment of the online Fiduciary Security registration system, then the fiduciary registration office is obliged to complete it no later than 60 (sixty) days from the date when the electronic fiduciary security registration administration system takes effect. And in number 5 it states that the application for registration of Fiduciary Security as referred to in number 4 cannot be resolved, so the application must be made electronically.

We can see in the Regulation of the Minister of Law and Human Rights Number 9 of 2013 that legal services, especially Fiduciary Security registration, have left manual or conventional methods and have switched electronically (Online system). And in number 5 states that the application for registration of Fiduciary Security as referred to in number 4 cannot be resolved, so the application must be made electronically. We can see in the Regulation of the Minister of Law and Human Rights Number 9 of 2013 that legal services, especially Fiduciary Security registration, have left manual or conventional methods and have switched electronically (Online system). And in number 5 states that the application for registration of Fiduciary Security as referred to in number 4 cannot be resolved, so the application must be made electronically. We can see in the Regulation of the Minister of Law and Human Rights Number 9 of 2013 that legal services, especially Fiduciary Security registration, have left manual or conventional methods and have switched electronically (Online system). In implementing Fiduciary Security registration electronically (Online system) Of course, legal certainty must be guaranteed both for the fiduciary, the fiduciary as well as for third parties. Providing legal certainty as the goal of online Fiduciary Security registration. And to further ensure legal certainty for the parties, the Notary himself will register the Fiduciary Guarantee online by entering the data in accordance with the deed of charge which he made of course by obtaining the power of the fiduciary recipient and also by remembering the username and password to enter the Registration service menu. Online fiduciary guarantees are only owned by the Notary as an authorized public official.

Notary as a public official who is authorized to make an authentic Deed can be held responsible for his actions in connection with his work in making the deed. The scope of his responsibility includes the material correctness of the deed he makes. Material truth here can be in the form of truth that is proven and accounted for materially to the parties, namely:

1. Civil notary responsibility for the material accuracy of the deed he makes; 
2. The notary's responsibility is criminally responsible for the material correctness of the deeds he has made;

3. The responsibility of the Notary based on the position regulations of the Notary regarding the material accuracy in the deed he makes;

4. The notary's responsibility in carrying out his/her job duties is based on the Notary's code of ethics.

By registering a Fiduciary Guarantee, of course, you can easily find out information about the guarantee bond and the object that is the guarantee, considering that this is also regulated in Article 13 of the Fiduciary Guarantee Law. Online registration of Fiduciary Security can provide information about the giver and recipient of fiduciary, the guaranteed principal agreement, the guarantee value and the collateral object in accordance with the Notary Deed.

After completing the data filling by the authorized Notary Public, proof of registration of fiduciary security will be obtained and we are required to pay a registration fee at a specified bank. Then the certificate can be printed from the transaction list menu in online Fiduciary. And the Fiduciary Guarantee Certificate contains words commonly called irah-irah, "FOR JUSTICE BASED ON GOD ALMIGHTY ", as written in Article 15 paragraph (1) of the Fiduciary Guarantee Law so as to provide legal certainty for both the fiduciary and the fiduciary recipient, in connection with the transfer of property rights to movable property from the fiduciary in trust to fiduciary. Then followed by information regarding the identity of the fiduciary giver and recipient, the guaranteed principal agreement, the guarantee value and the guarantee object in accordance with the Notary deed as well as the Fiduciary Registration Office along with the endorsement from the Head of the Regional Office of course on behalf of the Minister of Law and Human Rights of the Republic Indonesia as written in Article 15 paragraph (1) of the Law on Fiduciary Security so as to provide legal certainty for both the fiduciary and the fiduciary, in connection with the transfer of property rights to movable property from the fiduciary in trust to the fiduciary. Then followed by information regarding the identity of the fiduciary giver and recipient, the guaranteed principal agreement, the guarantee value and the guarantee object in accordance with the Notary deed as well as the Fiduciary Registration Office along with the endorsement from the Head of the Regional Office of course on behalf of the Minister of Law and Human Rights of the Republic Indonesia. as written in Article 15 paragraph (1) of the Law on Fiduciary Security so as to provide legal certainty for both the fiduciary and the fiduciary, in connection with the transfer of property rights to movable property from the fiduciary in trust to the fiduciary. Then followed by information regarding the identity of the fiduciary giver and recipient, the guaranteed principal agreement, the guarantee value and the guarantee object in accordance with the Notary deed as well as the Fiduciary Registration Office along with the endorsement from the Head of the Regional Office of course on behalf of the Minister of Law and Human Rights of the Republic Indonesia. And to see the identity of the Notary tappers, you can use the E-ID of the tappers considering that in the construction in accordance with Article 6 paragraph (1) of the revised Perpres on E-ID (Perpres No. and validation of population identification data (previously in public service). Meanwhile, based on Article 1 number (8) of the Presidential Decree E-ID, it is 
stated that the security code is an identification that shows the identity of the resident precisely and accurately as self-authentication which ensures that the population documents belong to that person. Furthermore, in paragraph (2) of the revised Perpres on E-ID, it is stated that the electronic record as referred to in paragraph (1) contains the bio, signature, passport photo, and handprint of the population concerned.

Currently, there is only one KTP ownership for each person because they have used the chip in the E-ID and contain the bio, signature, passport photo, and handprint of the population concerned so that the possibility of fraud is getting smaller. Of course, it is different from the implementation of conventional KTP, where the implementation system is still in shambles, so it is not surprising if we see in practice one person has several KTPs from different regions. However, the concept of cyber notary does not disappear immediately, this is evidenced by the issuance of the Circular of the Director General of General Legal Administration of the Ministry of Law and Human Rights of the Republic of Indonesia Number AHU-06.OT.03. 01 dated 5 March 2013 concerning the Enforcement of the Fiduciary Security Registration Administration System electronically (Online system) which is then regulated in the Regulation of the Minister of Law and Human Rights Number 9 of 2013. Username and password provided by the Directorate General of General Legal Administration in accessing the Fiduciary Online menu are only owned by Notaries. So it is hoped that notaries will be careful so that the username and password they have is not known and used by unauthorized people.

The notary's ownership of a username and password in accessing the online Fiduciary menu organized by the Ministry of Law and Human Rights, especially the Directorate General of General Legal Administration, clearly states that a notary is a public official authorized to register for Fiduciary Security. After the Notary enters his/her username and password to register the Fiduciary Security electronically, the Notary is then required to fill in the registration fields according to the data and information held. Notaries who play a role from the beginning of the online Fiduciary Guarantee registration process certainly have an important role in this. In essence, everything is as stated in the Fiduciary Guarantee deed made by the Notary and is the responsibility of the Notary.

In this case, the condition of the fiduciary security registration system, the database cannot be monitored regarding the objects that have been guaranteed. Because refiduciary against objects that have become Fiduciary Security is indeed prohibited as regulated in Article 17 of the Fiduciary Guarantee Law. And then the burden of responsibility lies in the authentic deed made by the Notary, because it becomes the basis for knowing the explanation of the Objects that are the object of the Fiduciary Guarantee, so the Notary Public must provide a detailed and detailed explanation regarding the object which is the object of the Fiduciary Guarantee. Also considering the notary's deed remains the responsibility of the Notary even though the Notary Protocol has been submitted or transferred to the depositor of the Notary protocol in accordance with Article 65 of Act No. 30 of 2004 concerning Notary Position in conjunction with Act No. 2 of 2014. Amendments to the Act No. 30 of 2004 concerning the Position of Notary Public. So it can be said that the notary is responsible for the deed he makes until the end of his life even though the notary has ended his term of 
office. In the manual Fiduciary Registration System, the applicant must register at KPF by bringing a number of physical documents as registration requirements.

If all the requirements are met, the KPF officer will record the application for registration in the Fiduciary Register Book and issue a Fiduciary Guarantee Certificate. Whereas in the electronic fiduciary registration administration system, the applicant only needs to access the website www.sisminbakum.go.id, fill in the required data in the fiduciary security registration application form, make PNBP payments at the perception bank and finally, re-access the website to print the Fiduciary Guarantee Certificate.

\subsection{Barriers and Solutions in Implementation Registration of Fiduciary Online Guarantee at the Directorate General of General Legal Administration (Ditjen AHU), Ministry of Law and Human Rights of the Republic of Indonesia}

Notaries to register the guarantee deed fiduciary created. The birth of this policy as a Notary Public must be more vigilant because online Fiduciary registration can be done alone at the Notary's office. Notaries must also prepare both in terms of office readiness, especially equipment and security for the use of the system and it is recommended not to leave it to employees for the registration, because the responsibility of a notary as a general official must be more careful The use of this online fiduciary system still has many obstacles, such as the old law in Article 12 of Act No. 42 of 1999, which states that fiduciary must be registered at the office of the Ministry of Law and Human Rights. Since there is a new regulation, the fiduciary registration process can be done at the respective Notary's office. In Article 25 of the UUJF, it is stated that the fiduciary recipient provides the fiduciary registration office regarding the abolition of fiduciary security by attaching a statement regarding the cancellation of debt, the release of rights or the destruction of objects that are the object of the fiduciary guarantee, but in fiduciary on line.

The problem regarding Roya's fiduciary certificate has not been accommodated. Another obstacle is that the fiduciary registration carried out at the Notary's office requires a smooth internet connection, if the connection is interrupted some data may not be stored on the server. Before it was database where the fiduciary recipient can check whether the goods or objects of fiduciary have previously been registered. The constraints mentioned above can affect the Notary Accountability.

The obstacle in this case is the registration of Fiduciary Security which we can see in the laws and regulations governing the Fiduciary Guarantee and Fiduciary Guarantee Registration Procedures. Obstacles to this regulation occur because the laws and regulations regarding the Fiduciary Guarantee and Fiduciary Security Registration Procedures still have many shortcomings and weaknesses, which these deficiencies and weaknesses can hinder the registration of Fiduciary Security. Article 11 paragraph (1) UUJF, says "objects that are burdened with Fiduciary Security must be registered". This article only states that objects guaranteed to be fiduciary must be registered. This article creates confusion.

The title of the second part of Chapter III of the Fiduciary Security Act is Fiduciary Security Registration. Thus, what is registered is of course the Fiduciary Guarantee imposed on an object. However, the clause of Article 11 above shows that what is 
registered is the object, that is, the object which is subject to the Fiduciary Guarantee. Likewise, the explanation of Article 11 of the UUJF shows that what is registered is an object that is burdened with a Fiduciary Guarantee. However, the articles of Article 12 paragraph (1) and Article 13 paragraph (1) state that what is registered is "Guarantee Fiduciary "not" object "which is imposed with a Fiduciary Guarantee. This will create confusion and will raise questions. If what is registered is an object, how is it possible to register an object in the form of stock (for supply purposes or for trading) if the object changes from time to time, both in terms of its quantity or volume as well as its type and brand.

Article 11 paragraph (1) of the UUJF should state that what must be registered is the Fiduciary Guarantee, not the object. Registration of the Fiduciary Guarantee will also result in the registration of objects that are burdened with the Fiduciary Guarantee. In addition, Article 11 paragraph (1) of the UUJF states that objects that are burdened by the Fiduciary Guarantee must be registered. Must be registered with the intention of fulfilling the principle of publicity in the Fiduciary Security Registration. This article does not explicitly state when the Fiduciary Guarantee must be registered. Whether after the Fiduciary Security Deed has been drawn up, then the fiduciary recipient or his proxy must at that time also register the Fiduciary Guarantee or can the Fiduciary Guarantee be registered by the fiduciary recipient or his proxy when it is suspected that the Fiduciary Guarantee will cause problems.

Structural Barriers that lack legal discipline The legal system has a structure. That structure is the institutions related to the Fiduciary Registration Guarantee. The structure of this Fiduciary Security Registration consists of the Fiduciary Registration Office, Bank or Financing Institution and Notary. How does the Fiduciary Registration Office carry out the Fiduciary Registration, whether the Bank or other Financing Institution has all of them register the Fiduciary Guarantee and how it is related to the Notary.

Notary is one of the structures of Fiduciary Security Registration because Notary is an official or can be said to be an institution that plays a role in fiduciary registration. The notary relation in Fiduciary Security Registration is in Article 5 paragraph (1) UUJF expressly states that the imposition of objects with fiduciary security is made by a Notary Deed in Indonesian and is a Fiduciary Security Deed. The intention of the legislators is that the Fiduciary Security Deed must be a deed made by a Notary Public, not an underhanded deed. One of the reasons the legislators stipulated a Notary Deed was that a Notary Deed was an authentic deed so that it had perfect evidentiary power.

Cultural Barriers, what is meant by legal culture is human attitudes towards the law and the legal system - their beliefs, values, thoughts, and hopes. Legal culture has a big role in creating legal certainty. A low legal culture will result in the inability to achieve the meaning of legal certainty itself. Culture is closely related to the behaviors that exist in social life. Behavior that is carried out by a person or a part of society that is done repeatedly and continuously, which ultimately will make the behavior a culture for someone or for some members of society. The UUJF states that the Fiduciary Guarantee must be registered, but it does not explicitly state when the fiduciary must be registered, whether after the Fiduciary Security Deed is completed then it is 
immediately registered or when. Can fiduciary registration be registered if the Fiduciary Guarantee is suspected to cause problems. UUJF does not provide sanctions if the Fiduciary Guarantee is not registered. UUJF only says that the Fiduciary Guarantee is registered, it will fulfill the principle of publicity, as well as a guarantee of certainty to Creditors regarding objects that have been subject to the Fiduciary Guarantee. Registration will result in material rights for fiduciary recipients. Because it is not clear when the Fiduciary must be registered and the absence of strict sanctions for parties who do not register the Fiduciary Guarantee will result in someone not obeying to comply with the Fiduciary Guarantee Law.

Behavior that is not obedient to the law if it is repeated repeatedly and continuously will result in the behavior becoming a culture. If it has become a culture, it will be difficult to change that culture. If there are strict sanctions for parties who do not register the Fiduciary Guarantee, it will automatically form legal behavior that complies with the law, which behavior will later become a legal culture for parties who will use the Material Guarantee Agency.

Behavior that is not obedient to the law if it is repeated repeatedly and continuously will result in the behavior becoming a culture. If it has become a culture, it will be difficult to change that culture. If there are strict sanctions for parties who do not register the Fiduciary Guarantee, it will automatically form legal behavior that complies with the law, which behavior will later become a legal culture for parties who will use the Material Guarantee Agency. Fiduciary Guarantee. Behavior that is not obedient to the law if it is repeated repeatedly and continuously will result in the behavior becoming a culture. If it has become a culture, it will be difficult to change that culture. If there are strict sanctions for parties who do not register the Fiduciary Guarantee, it will automatically form legal behavior that complies with the law, which behavior will later become a legal culture for parties who will use the Material Guarantee Agency. Fiduciary Guarantee.

\subsection{Solution in the implementation of Registration of Fiduciary Online Guarantee at the Directorate General of General Legal Administration (Ditjen AHU), Ministry of Law and Human Rights of the Republic of Indonesia}

Solutions to overcome the Regulatory Substance Barriers (Act No. 42 of 1999 concerning Fiduciary Security). Lately, there have been many tendencies to make Fiduciary Collateral binding under the hands of some creditors, and legal protection guarantees for creditors are usually carried out by agreement of "selling power/power of attorney for withdrawal of guarantee" or "willingness that the goods will be taken physically" if Default debtors who tend to cause their own problems. As well as the use of "fiduciary power to guarantee" under hand also has the potential to be prone to the legality of the signature in the power of attorney, where if the Debtor has the potential to become stuck, a Notary fiduciary binding will be carried out based on the power of attorney and registration will be carried out at the Fiduciary Security Registration office.

Regulation of the Minister of Finance of the Republic of Indonesia No. 130/PMK.010/2012 which is very precise in order to guarantee legal certainty for the 
parties concerned the existence of Regulation of the Minister of Finance of the Republic of Indonesia No. 130/PMK.010/2012 which comes into force after two months from the date of promulgation.

The PMK was promulgated in Jakarta on August 7, 2012, has brought fresh air to finance companies and consumers in connection with the transfer of ownership rights to motorized vehicles from consumers in trust (Fiduciary) to finance companies to support good corporate governance and ensure a sense of justice, benefit, legal certainty in the world of law and the world of business by regulating the following matters:

1. Emphasizing the requirement to register fiduciary security at the Fiduciary Registration Office.

2. Confirming the registration period is a step to ensure legal certainty.

3. Suppress actions that are contrary to the sense of justice by regulating the procedure for withdrawing fiduciary items.

4. The application of strict sanctions against violations of these provisions is necessary as a coercive measure as well as for the registration of objects of fiduciary security.

It gives more sense of justice because by registering the object of fiduciary security, if the Debtor is in default, the methods of execution will be pursued in accordance with Act No.42 of 1999. Regulation of the Minister of Finance of the Republic of Indonesia No. 130/PMK.010/2012 only applies to Financing Institutions, because the regulation is, among other things, to encourage economic growth by increasing state revenue from the non-tax state revenue sector (PNBP). This substantive matter cannot be separated from the role of the structure that makes the UUJF. UUJF is a product of the law made by the competent body.

When viewed from the order of legislation in Indonesia, the position of law is higher than that of a Ministerial Regulation. As it is known, in the case of a higher level of statutory regulations contradicting a lower level of statutory regulations, then the higher level provisions apply. If the UUJF does not strictly regulate the deadline for registration of fiduciary security, and although the mandatory provisions with the deadline for fiduciary registration are regulated in a Minister of Finance Regulation, the provisions in UUJF will apply. Because of the foregoing, the above-mentioned Regulation of the Minister of Finance must be followed up with the Revision of Act No. 42 of 1999 or legal reform of Act No. 42 of 1999 concerning fiduciary guarantees due to a crisis of trust in business actors, as well as Government Regulation Number 21 of 2015, then a higher provision applies. If the UUJF does not strictly regulate the deadline for registration of fiduciary security, and although the mandatory provisions with the deadline for fiduciary registration are regulated in a Minister of Finance Regulation, the provisions in UUJF will apply. Because of the foregoing, the aforementioned Minister of Finance Regulation must be followed up with the Revision of Act No. 42 of 1999 or legal reform of Act No. may be implemented. 42 of 1999 concerning fiduciary guarantees due to a crisis of trust in business actors, as well as Government Regulation Number 21 of 2015, then a higher provision applies. If the 
UUJF does not strictly regulate the deadline for registration of fiduciary security, and although the mandatory provisions with the deadline for fiduciary registration are regulated in a Minister of Finance Regulation, the provisions in UUJF will apply. Because of the foregoing, the aforementioned Minister of Finance Regulation must be followed up with the Revision of Act No. 42 of 1999 or legal reform of Act may be implemented. 42 of 1999 concerning fiduciary guarantees due to a crisis of trust in business actors, as well as Government Regulation Number 21 of 2015, and although the mandatory provisions with the deadline for fiduciary registration are regulated in a Regulation of the Minister of Finance, the provisions in UUJF apply. Because of the foregoing, the aforementioned Minister of Finance Regulation must be followed up with the Revision of Act No. 42 of 1999 or legal reform of Act may be implemented. 42 of 1999 concerning fiduciary guarantees due to a crisis of trust in business actors, as well as Government Regulation Number 21 of 2015, and although the mandatory provisions with the deadline for fiduciary registration are stipulated in a Minister of Finance Regulation, the provisions in UUJF apply. Because of the foregoing, the aforementioned Minister of Finance Regulation must be followed up with the Revision of Act No. 42 of 1999 or legal reform of Act No. may be implemented. 42 of 1999 concerning fiduciary guarantees due to a crisis of trust in business actors, as well as Government Regulation Number 21 of 2015, concerning Fiduciary Security Registration Procedures and Fiduciary Security Deed Making Fees. Which is where Chapter II concerning Fiduciary Security Registration Article 4 where the Fiduciary Guarantee must be registered no later than 30 days from the making of the Fiduciary Guarantee Deed.

To overcome the structural barriers that occur in fiduciary registration, a change to existing structures is needed. Such changes will result in the structure working properly, thus bringing about significant changes in the registration of fiduciary guarantees on March 5, 2013, the Directorate General of General Legal Administration of the Ministry of Law and Human Rights has launched online Fiduciary. Online fiduciary is a breakthrough by the Directorate General of General Legal Administration of the Ministry of Law and Human Rights in providing services to the public. Through new methods, it is hoped that fiduciary legal services will be faster, more accurate, and free from extortion and the public will be more aware of the law and legal discipline.

However, the new pattern also needs careful preparation, assuming that online fiduciary registrants can do it themselves at the notary office they choose. In this case, the notary must also prepare the equipment and safety for the use of the equipment system in his office. It is recommended that the notary public should not hand over the job to staff who are not very good at it, given their more careful responsibilities. Notary on the one hand as a public official and on the other hand as a professional who must really understand, appreciate, and practice the Law on the Position of Notary Public, code of ethics, and legislation in order to avoid malpractice. Notary under the auspices of a credible professional organization is part of civil society that contributes to upholding the principles of good governance. He will support development considering the authentic Deed is made the basis for the parties 
to make agreements, and build trust. Notaries need to pay attention to several things related to the online fiduciary system, and need to emphasize the element of prudence for example, in addition to making a fiduciary guarantee deed, it is also at the same time registering the deed made.

Regarding the NPWP/NIK entry on the display of the identity of the fiduciary (for individuals), the Notary should request a complete file. But online fiduciary also has some drawbacks. First; database information about registered fiduciary security objects cannot be accessed through this system because as the Deed, all made by a notary. In this context, the notary must be careful because it is related to the value input owed whether it belongs to the fiduciary or the debtor. For Banks and other financing institutions, it is necessary to have a legal awareness regarding the importance of registration and the legal consequences it causes. In addition to legal awareness, a legal culture is also required for Banks or other Financing Institutions to carry out what is already regulated by laws and regulations, namely the obligation to register for Fiduciary Security. For Banks and other financing institutions, it is necessary to have a legal awareness regarding the importance of registration and the legal consequences it causes. In addition to legal awareness, a legal culture is also required for Banks or other Financing Institutions to carry out what is regulated by laws and regulations, namely the obligation to register for Fiduciary Security. For Banks and other financing institutions, it is necessary to have a legal awareness regarding the importance of the meaning of registration and the legal consequences it causes. In addition to legal awareness, a legal culture is also required for Banks or other Financing Institutions to carry out what is regulated by laws and regulations, namely the obligation to register for Fiduciary Security.

The norms and rules contained in the UUJF are substantive in nature. These norms and rules will in turn influence the legal culture. Unclear norms will result in a bad legal culture. Besides, the legal culture is not static. The legal culture changes according to society. So to overcome cultural barriers in the registration of the Fiduciary Guarantee is by means of legal counseling. So that the community understands the law and leaves/forgets the thoughts of old legal cultures which are not in accordance with the law while building new legal awareness.

Another effort to build legal awareness is obedience to the Law Order and likewise the enforcement of laws that are positivated by the State's power, it is widely known and recognized that it is not always possible to ascertain based on the strength of sanctions alone. Legal awareness is the whole complex of the willingness of citizens to behave in accordance with the requirements stipulated by law. The third effort is to build legal communication. Legal communication is to instill legal awareness. This legal communication can be done by means of socializing about Fiduciary, spreading news about the issue of fiduciary security and registration, in which the issue is attempted to build compliance with subjects to obey the law and the law can be enforced properly. The fourth effort is to reform the technology and information program.

The use of the online system in Fiduciary services aims to facilitate the implementation of registration of fiduciary guarantees, lest such good purposes can be misused by 
irresponsible parties and take advantage of technological sophistication for their own interests, so that it can harm other parties. ${ }^{19}$

Solutions to overcome internet server connections at the Directorate General of General Legal Administration (Ditjen AHU), Ministry of Law and Human Rights of the Republic of Indonesia. Because an internet connection is a software tool that plays an important role because if the server is an error, Notaries throughout Indonesia will not be able to access applications that are on www.sisminbakum.go.id, then it should and deservedly. The Directorate General of General Legal Administration (Ditjen AHU) of the Ministry of Law and Human Rights of the Republic of Indonesia uses a strong, reliable internet server, not frequent errors because many servers are used every day.

Solution to overcome Paper used in printing Fiduciary Guarantee certificates, there should be regulations governing the specifications of the paper used in printing the Fiduciary Guarantee Certificate.

The solution to overcome Notary fees is more expensive, Notaries must comply with and follow Government Regulation Number 21 of 2015,concerning Procedures for Fiduciary Security Registration and Fiduciary Security Deed Making Fees and Government Regulation Number 10 of 2015 concerning Amendments to Government Regulation Number 45 of 2014 concerning Types and Rates of Non-Tax State Revenues Applicable to the Ministry of Law and Human Rights, and not burdening the public with expensive fees and above the fees set by the government, and there must be control from the government and society.

\section{Closing}

\subsection{Conclusion}

1. The registration procedure for the Online Fiduciary Guarantee Certificate at the Directorate General of General Legal Administration (Ditjen AHU) of the Ministry of Law and Human Rights of the Republic of Indonesia is an initial process where the procedure for obtaining a Fiduciary Guarantee Certificate through Online Registration has been launched by the Directorate General of General Legal Administration (Ditjen AHU) ) Ministry of Law and Human Rights of the Republic of Indonesia as a way to prevent alleged extortion at the Ministry and low and fast costs.

2. Obstacles in Registration of Online Fiduciary Guarantee Certificate at the Directorate General of General Legal Administration (Ditjen AHU) of the Ministry of Law and Human Rights of the Republic of Indonesia are starting from the substance of Act No. 42 of 1999 concerning Fiduciary Guarantee, Structural Human Rights, Cultural Barriers, Server Barriers at the Directorate

\footnotetext{
19 Interview with Notary Dwi Fratmawati, SH, MKn St. Ratan Cilik, Banjardowo, Genuk, Semarang, March 3 2016, 09.45-10.00 WIB.
} 
General Legal Administration (Ditjen AHU) of the Ministry of Law and Human Rights of the Republic of Indonesia, Paper Barriers in printing Fiduciary Guarantee Certificates, as well as barriers to higher cost of notaries. The solution is to overcome the obstacles in the registration process for the Online Fiduciary Guarantee Certificate of the Directorate General of General Legal Administration (Ditjen AHU), Ministry of Law and Human Rights of the Republic of Indonesia.

\subsection{Suggestion}

1. Act No. 42 of 1999 concerning Fiduciary Security must be immediately amended and/or replaced because there are many unclear articles which have multiple interpretations and there is no firm sanction if Fiduciary is not registered.

2. Based on the above conclusions, it is advisable to hold a further seminar on the implementation of fiduciary because fiduciary is a guarantee for moving objects where its control can change hands easily.

3. To realize or realize the principle Publicity There should and should be an application provided at the Directorate General of General Legal Administration (Ditjen AHU) of the Ministry of Law and Human Rights of the Republic of Indonesia, which can be accessed by the general public specifically to find out whether the motorbike/car to be purchased is bound by a guarantee or not.

4. Serverat the Directorate General of General Legal Administration (Ditjen AHU) of the Ministry of Law and Human Rights of the Republic of Indonesia must be stronger because considering the increasing number of Notaries who usewebsitewww.sisminbakum.go.id and remember where the office is The Directorate General of General Legal Administration (Ditjen AHU) of the Ministry of Law and Human Rights of the Republic of Indonesia is located in Jakarta where there are many natural disasters, especially floods. so it must be anticipated.

5. To anticipate obstacles and make it easier for Notaries in remote areas of the country who are not in big cities in the future, it is expected that the payment for Fiduciary Security Registration is not only Bank Negara Indonesia (BNI) but Bank Perception must be added.

6. Do not set a price above the price set by the Government.

7. Creditors/Banks must register collateral/guarantees which are Fiduciary

8. The community must actively participate in controlling the law, especially the issue of registration of a Fiduciary Certificate.

\section{References}

Books:

[1] Salim HS. (2004). Perkembangan Hukum Jaminan Di Indonesia, Jakarta : PT Raja Grafindo Persada. 
[2] Dwi Fratmawati. (2004). Perlindungan Hukum Bagi Kreditor terhadap Pelaksanaan Fidusia, Semarang, Unissula.

[3] Rachmadi Usman. (2009). Hukum Jaminan Keperdataa, Jakarta: Sinar Grafika.

[4] Ali Mansyur. Hukum Perdata Jaminan. Semarang, Bagian Hukum Perdata Unissula.

[5] R.Subekti (1978). Jaminan-Jaminan Untuk Pemberian Kredit menurut Hukum Indonesia, Bandung: Alumni.

[6] Salim HS,Op Cit.

[7] J.Satrio (2002). Hukum Jaminan, Hak Jaminan Kebendaan, Bandung: PT.Citra Aditya Bakti.

[8] Oey Hoey Tiong. (2000). Fidusia sebagai Jaminan Unsur-unsur Perikatan, Jakarta : Ghalia Indonesia.

[9] Yunaldi. (2015). Usulan Penelitian, Program Magister Ilmu Hukum. Semarang: Unissula.

Internet:

http://download.portalgaruda.org/article.phpkepastianhukumdalampemberlakuansis temadministrasipendaftaranjamminanfidusiaelektronikterkaitdenganlaranganfidusiau lang. accessed on 27 October 2020, at 14.35 WIB.

Regulation:

[1] Act No. 42 of 1999 concerning Fiduciary Guarantee Article 14 paragraph.

[2] Act No. 42 of 1999 concerning Fiduciary Guarantee Article 1 paragraph (1).

[3] Act No. 42 of 1999 concerning Fiduciary Guarantee Article 1 paragraph (2). Interview:

Interview with Notary Dwi Fratmawati, SH, MKn. St. Ratan Cilik, Banjardowo, Genuk, Semarang, March 3 2016, 09.45-10.00 WIB. 